\title{
薬剤師教育におけるチーム基盤型学習の有用性の検討
}

伊藤雄大, 高田麻季, 飯田真之, 宇田篤史, 住吉霞美, 秋山恵里, 丸上奈穂, 丹田雅明 野間千尋, 山本和宏, 五百蔵武士, 木村丈司, 西岡達也, 久米 学, 槇本博雄, 矢野育子* 神戸大学医学部附属病院薬剤部

\section{Evaluation of Team-based Learning as a Teaching Method for Pharmacist Education}

Takahiro Ito, Maki Takata, Masashi Iida, Atsushi Uda, Kasumi Sumiyoshi, Eri Akiyama, Naho Marugami, Masaaki Tanda, Chihiro Noma, Kazuhiro Yamamoto, Takeshi Ioroi, Takeshi Kimura, Tatsuya Nishioka, Manabu Kume, Hiroo Makimoto and Ikuko Yano* Department of Pharmacy, Kobe University Hospital

\author{
$\left[\begin{array}{l}\text { Received November 14, } 2017 \\ \text { Accepted March 13, } 2018\end{array}\right]$
}

Team-based learning (TBL) is an active learning method which has been designed to help students solve problems both by themselves and as a team. In this study, TBL was introduced in the journal club (gathering to read and discuss medical papers) for pharmacists, and its effectiveness was compared with that of a traditional lecture. The subjects, 29 pharmacists at Kobe University Hospital, were randomly allocated to the lecture group and TBL group. The pre-test was conducted two months before the journal club, and the post-tests were conducted immediately and one month after the journal club. There was no significant difference in the background data of the pharmacists between the lecture group and the TBL group. The score differences between the pre-test and the post-test immediately after the journal club were not significant $(11.4 \pm 2.3$ points (mean $\pm \mathrm{SD})$ in the TBL group, $8.8 \pm 4.2$ points in the lecture group, $P=0.14)$. The post-test scores immediately after the journal club in the TBL group (19.6 \pm 0.5 points) were significantly higher compared with those in the lecture group $(17.8 \pm 1.5$ points $)(P<0.01)$, and the learning effect provided by TBL tended to be maintained one month after the TBL. In conclusion, TBL was an alternative method of the ordinal lecture and may be a useful learning method for pharmacists to read medical papers critically compared with the ordinal lecture.

Key words — team-based learning, pharmacist education, journal club, active learning

\section{緒 言}

薬学分野における臨床教育において, 大学など の高等教育では学習者の問題発見および解決能 力, 能動的学習を促進するためのアクティブラー ニングを取り入れた授業が行われ，教員中心から 学習者中心へ, 講義から少人数グループ中心の学 習へと変換しつつある. ${ }^{1,2)}$ 一方, 卒後の薬剤師教 育において，アクティブラーニングの有用性を検 証した報告はほとんどない.アクティブラーニン グの教育手法としては, 問題基盤型学習（problem- based learning: PBL）が医療系学部において広く 用いられており, 臨床で必要とされる問題解決能 力の育成に有効であると報告されている. ${ }^{3)}$ 一方 で, 少人数グループにて学生主導で授業を進める ためには，グループ数に応じたチューターを必要 とし, 学生数に応じた教員の確保を必要とする. ${ }^{4)}$ 加えて PBLでは, 各グループで討論するために 個別のスペースを要するという問題点がある. ${ }^{5)}$

チーム基盤型学習 (team-based learning: TBL) は，個人とチームの双方から問題を解決していく プロセスにより学習を深める特徴を持ち, 経営学

\footnotetext{
*テ650-0017 兵庫県神戸市中央区楠町7-5-2
} 
や自然科学の教育課程で用いられてきた能動的学 習方法である。 ${ }^{6,7)}$ TBL 学習活動のプロセスは, 「予 習」,「準備確認」,「応用」から構成され, ${ }^{4)} 「$ 予習」 では, 教員が事前に指定した資料（教科書や文献, 予習課題など）に基づき自己学習を行う。「準備 確認」では，まず学生一人ひとりに多肢選択テス ト（individual readiness assurance test: IRAT）を実 施し, 引き続いて同じテストに学習グループで取 り組ませる (group readiness assurance test: GRAT). GRAT 終了後, 誤りとされた自分たちの回答を弁 護するチャンスがチームに与えられる(アピール). 最後に, IRAT, GRAT, アピールの状況に合わせて, 教員がピンポイントで補足説明を行う（フィード バック)。「応用」では,「予習」および「準備確認」 のステップで得た知識を使って解決すべき応用課 題にチームで取り組む，TBL は PBL と異なり，教 員一人当たりの学生数が多い場合においても教員 主導により少人数グループ学習を行うことができ る効率の良さと高い教育効果を併せもち, ${ }^{8,9)}$ 従来 型の講義に比べて学習成果が高かったとの報告も ある. ${ }^{10-12}$ 現在, TBL は世界的に医療分野の大学教 育に急速に広がっており, 日本でも幾つかの医療 系学部で学部教育に導入されている. ${ }^{13,14)}$ しかしな がら, 薬剤師の卒後教育における TBL の有用性に ついては未だ報告がない.

当院薬剤部では, 臨床医学系論文を批判的に吟 味する能力の修得を目指して, 臨床英語論文の抄 読会（ジャーナルクラブ）を 2016 年 2 月から開 始している，従来は，このジャーナルクラブを講 義形式で実施していたが，一方向性の教育となる ため参加者の準備状況が悪く, 理解度の向上・定 着が充分でないという問題点があった。そこで本 研究では，薬剤師を対象としたジャーナルクラブ に TBLを導入し，その有用性を明らかにするこ とを目的として, 講義群と TBL 群における比較 を行った。

\section{方 法}

\section{1. 対象}

対象は, 薬剤師歴が $1 \sim 8$ 年目の当院薬郕部所 属の薬剤師のうち, 研究に同意が得られた 29 名
とした。 なお, 事前に参加候補者に対して本研究 の目的や方法, 参加の任意性, 研究結果の論文で の公表, アンケート調査の実施などについて説明 し，同意が得られた者のみを参加者とした，該当 の講義あるいは TBL の実施前に行ったプレテス トのスコアと薬剤師歴を割り付け因子とし, 置換 ブロック法においてランダム化して参加者を 2 群 に分け，一方を TBL 群，もう一方を講義群に割 り当てた. TBL 群抢よび講義群への割り当て結 果は, ジャーナルクラブ 2 週間前に参加予定者全 員に知らせた。

\section{2. プレテストおよびポストテスト}

プレテストとポストテストの出題内容は, ジャーナルクラブ当日に使用する課題論文 (JAMA Psychiatry, 2014, 71, 397-403 $\left.{ }^{15}\right)$ に関するものとし， 同一の問題とした（図 1)。プレテストおよびポ ストテストは, 課題論文を読みながら解く 20 点 満点の正誤問題形式とし, 制限時間は 10 分間と した。出題内容は，英語論文の読解の際に重要と なると考えられる (1) PICO, (2)研究デザイン, (3) エンドポイント, (4)研究結果の4 項目を, CASP worksheet for RCT Japanese version 2.21 (http:// caspjp.umin.ac.jp/materials/caspsheets/files/RCT21j.

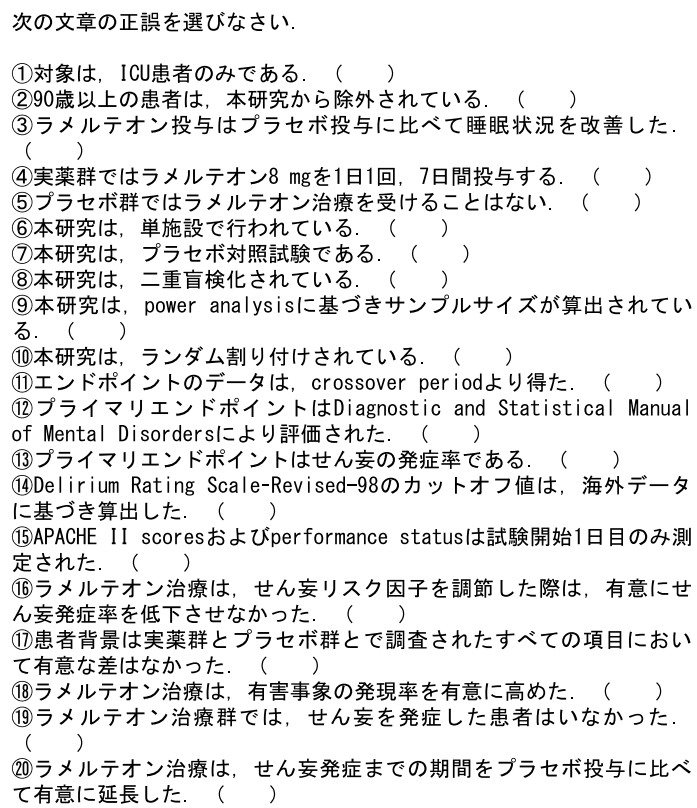

図 1 プレテストおよびポストテストの出題内容 
pdf, 2017 年 11 月 14 日)を参考に選択した. ジャー ナルクラブ 2 カ月前にプレテストを実施し, ジャーナルクラブ直後および 1 カ月後にポストテ ストを行った。各参加者の経時デー夕を紐づける ため，参加者はプレテストおよびポストテスト用 紙に英数字 4 桁の ID を記載した。なお，各テス 卜終了後課題論文は回収した。

\section{3. 研究デザイン}

プレテストとジャーナルクラブ直後のポストテ ストのスコアの差を主要評価項目とし，既報 ${ }^{12)}$ を 基に 2 群間の平均值の差を 7.5, 2 群共通の標準偏 差を 6.0, $\alpha$ エラー0.05, 検出力 0.8 としてサンプル サイズの計算を行い, 各群 11 例と算出した.

\section{4. 講義形式および TBL 形式}

講義形式および TBL 形式の両群に対して，課 題論文（JAMA Psychiatry, 2014, 71, 397-403 ${ }^{15)}$ ) を ジャーナルクラブ実施の 4 週間前に配布し，個人 学習を事前学習として課した。同一の教育担当者 1 名が講義群と TBL 群の両方を担当し，教育内 容は可能な限り同様となるようにした。講義形式 では，論文の PICO および CASP worksheet for RCT Japanese version 2.21 に記載されたチェックポイン 卜に関する講義を 57 分間, アンケートを 3 分間実 施した。 なお，講義形式のなかで，プレテストお よびポストテストで出題される内容はすべて網羅 するようにした，TBL 形式では，既報 ${ }^{2)}$ を参考に 以下の手順で行った。 (1) IRAT 5 分間, (2) GRAT 8 分間，(3アピールとフィードバック 7 分間，(4)論 文内容の解説 17 分間, 5応用課題 (症例検討) 20 分間, (6)アンケート3 分間, の計 60 分間とした. IRAT は, 1 問 5 点, 20 点満点の五者択一式テス トとし，内容はプレテストおよびポストテストと 同様, (1) PICO, (2)研究デザイン, (3)エンドポイ ント, (4)研究結果の 4 項目を選択した（図 2). GRAT は, IRAT と同一の問題とし, スクラッチカー ド (http://www.epsteineducation.com/home/about/ default.aspx, 2017 年 11 月 14 日）を用い，学習者 のみで正答に到達するまで議論を進行させるチー ムテストとした. GRATにおける得点は以下のよ うに設定した。 1 回目での正解：5点，2回目での

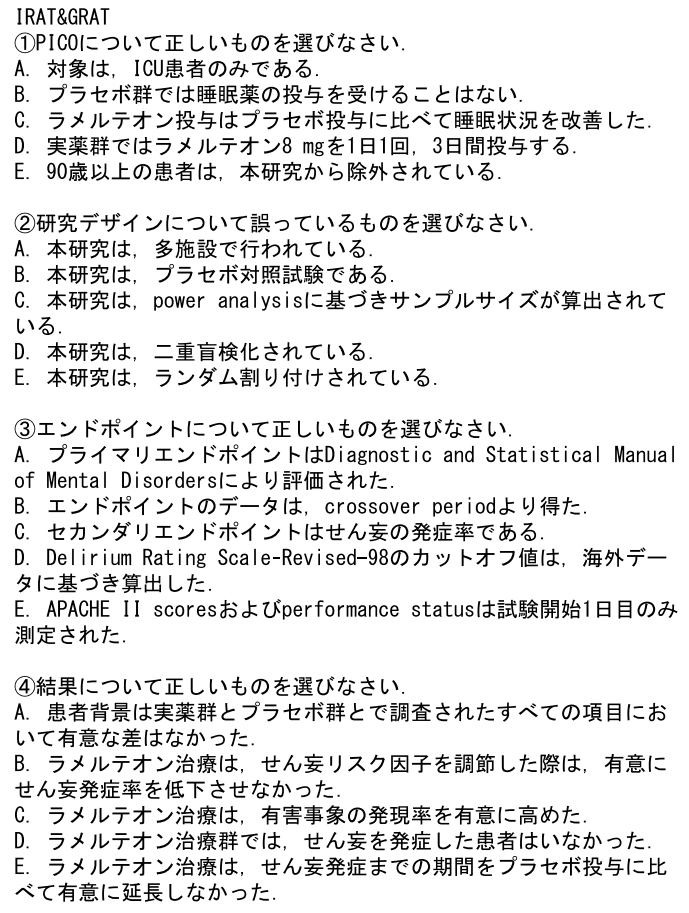

図 2 IRAT および GRAT の内容

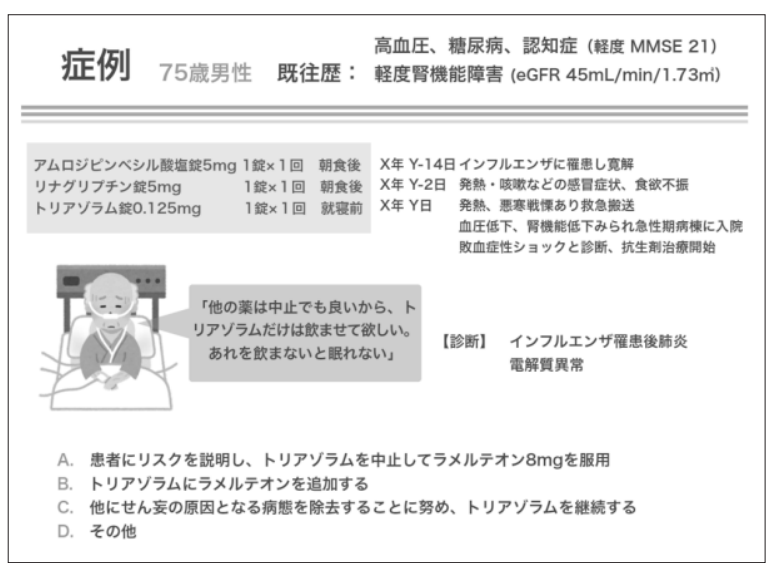

図 3 応用課題の内容

正解 : 3 点, 3 回目での正解 : 2 点, 4 回目での正解 : 1 点, 5 回目での正解 : 0 点. アピールとは,「問 題の正答が誤っている」あるいは「設問に不適切 な表現がある」などの点について参加者から司会 者に指摘することを呼び, フィードバックとは, 司会者による RAT の解答・解説のことを指す。論 文内容の解説は, CASP worksheet for RCT Japanese version 2.21 に沿って行った。応用課題としては, 論文の吟味から得られた知見を応用できる課題 （図 3）を提示した. ジャーナルクラブ終了後に両 
群それぞれに対して作成したアンケートを実施し た.アンケートでは, 既報 ${ }^{2)}$ で用いられたアンケー 卜を改変し,「(1) 薬剂師歴」,「(2) 性別」,「(3) 予習時間」,「(4) 今回のジャーナルクラブ参加前 のモチベーション」,「(5) 今回のジャーナルクラ ブの満足度」について調査した。 また，TBL 群の アンケートでは，設問（6）として「11論文のテー マ」,「(2)司会者の熱意」,「(3) IRAT 」,「(4) GRAT」, 「(5)グループでのアピール」, 「(6) RAT のフィード バック」,「(7)論文内容の解説」,「8)応用課題」,「(9) グループのメンバーの多様性」,「10時間配分」の 10 項目に関して，それぞれの満足度を 1〜 5 点の 5 段階で調査した。 TBL 形式のジャーナルクラブ の改善すべき点を分析するために，アンケートに 基づく顧客満足度分析を, 既報 ${ }^{16)}$ を参考に行った。

\section{5. 統計解析}

デー夕は平均 \pm 標準偏差で示し, すべての統 計解析にはSPSS ver 24（IBM）を用いた。解析 対象は，プレテスト，ジャーナルクラブ直後拈よ び 1 カ月後のポストテストのすべてのテストを受 けた参加者のみとした．対応のない 2 群間の比較 には，等分散が仮定できる場合には Student の $t$ 検定を用い，等分散が仮定できない時は Welch の $t$ 検定により解析した。 また，プレテストのス コア別にジャーナルクラブ直後のポストテストの スコアの改善度（前後でのスコアの差）を評価す るために直線回帰分析を用い, 回帰直線の比較に は共分散分析（analysis of covariance：ANCOVA） を用いた。 $P<0.05$ を統計学的に有意であると判 定した。

\section{結果}

対象となった参加者 29 名をランダム化して 2 群 に分け, 講義群 15 名, TBL 群 14 名とした（図 4). ジャーナルクラブの実施前に行ったプレテストの スコアと薬凨師歴は, 講義群で $9.0 \pm 3.4$ 点, 2.8 \pm 2.1 年, TBL 群で $8.1 \pm 2.4$ 点, $2.4 \pm 1.8$ 年で あり，2 群間に有意差は認めなかった（それぞれ

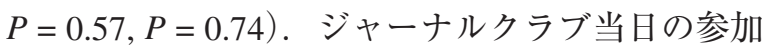
者は, 講義群 13 名, TBL 群 10 名であり, TBL

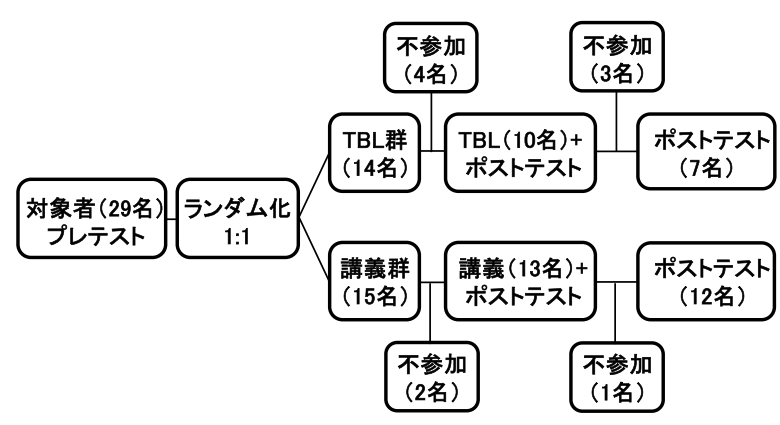

2力月前

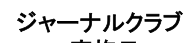

1力月後

図4 研究参加者の割り振り状況

群においては 4 名のグループが $1 つ, 3$ 名のグルー プが 2 つ計 3 グループに分けた。ジャーナルク ラブに参加する前のモチベーションにおいても，

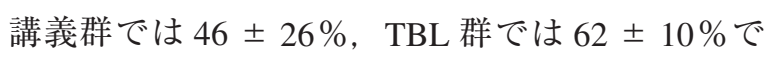
あり,両群間で有意差は認めなかった $(P=0.07)$. ジャーナルクラブ参加前の予習時間は, 講義群で は $1.10 \pm 0.64$ 時間, TBL 群では $0.50 \pm 0.41$ 時 間であり, TBL 群において有意に短かった（ $P=$ 0.04). プレテスト, ジャーナルクラブ直後およ びジャーナルクラブ 1 カ月後のポストテストのス コアの推移を図 5Aに示す，主要評価項目である プレテストとジャーナルクラブ直後のポストテス トのスコアの差は, 講義群が $8.8 \pm 4.2$ 点, TBL 群が $11.4 \pm 2.3$ 点であり有意差は認めなかった $(P=0.14)$. しかし，プレテストのスコアで調整 したプレテストとジャーナルクラブ直後のポスト テストのスコアの差は, TBL 群において有意に 高かった $(P=0.01$, 図 5B). ジャーナルクラブ 直後のポストテストのスコアは講義群が $17.8 \pm$ 1.5 点, TBL 群が $19.6 \pm 0.5$ 点であり, TBL 群に おいて有意に高かった $(P<0.01)$. ジャーナル クラブ 1 カ月後のポストテストのスコアは講義群 が $14.8 \pm 3.1$ 点, TBL 群が $17.1 \pm 2.1$ 点であり, 両群間で有意差は認めないものの, TBL 群にお いてスコアは高い傾向にあった $(P=0.10)$. また, ジャーナルクラブの直後と 1 カ月後のポストテス トのスコア差についても, 講義群が $2.9 \pm 2.4$ 点に 対して, TBL 群が $2.4 \pm 1.9$ 点であり有意な差は なかった $(P=0.66)$. なお, TBL群において, IRAT のスコアは $10.0 \pm 5.0$ 点であり, GRAT のス 
(A)

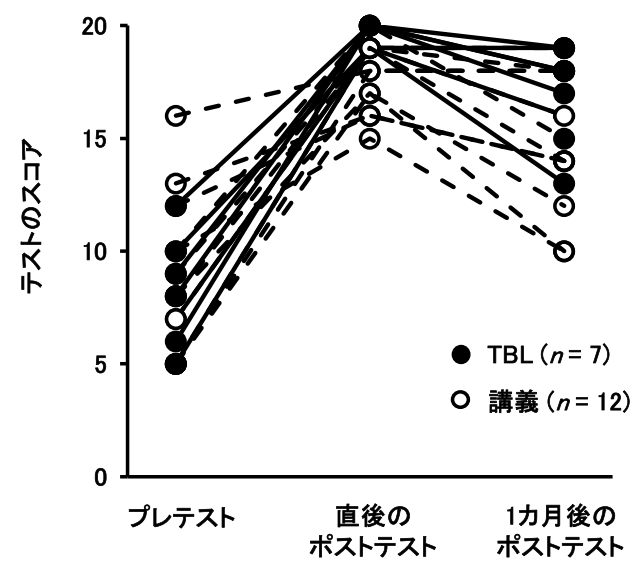

(B)

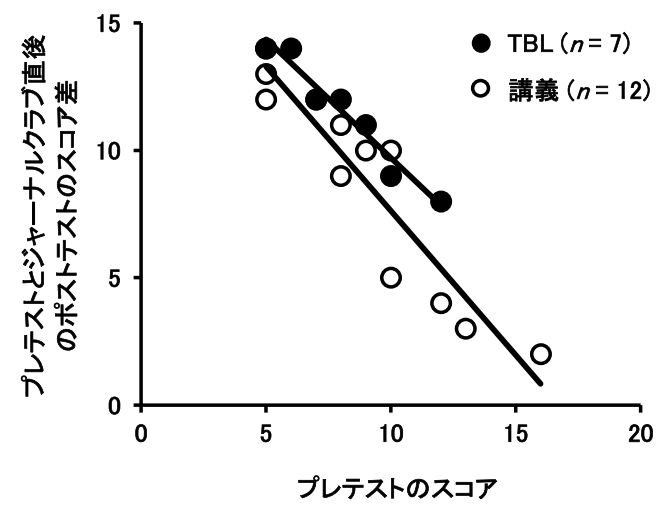

図 5 （A）講義群および TBL 群におけるプレテス ト, ジャーナルクラブ直後およびジャーナル クラブ 1 カ月後のポストテストのスコアの推 移,（B）講義群执よび TBL 群におけるプレテ ストスコアに対するジャーナルクラブ直後の ポストテストスコアの差

コアは全グループにおいて満点の 20 点であった.

アンケートの結果，ジャーナルクラブに対する 満足度は講義群で $77.9 \pm 16.7 \%$ ，TBL 群で 81.4 土12.1\%であり，両群間において有意差は認めな かった $(P=0.64)$. TBL についてジャーナルクラ ブの満足度に対する顧客満足度分析の結果を図 6 に示す，その結果，重要維持項目は，「(2)司会者 の熱意」および「(7)論文内容の解説」であった. また，要改善項目として挙がったのは，「(5)グルー プでのアピール」,「6 RAT のフィードバック」お よび「9グループのメンバーの多様性」であった.

\section{考察}

TBL 形式は講義形式と比較して，プレテスト
のスコアに対するジャーナルクラブ直後のポスト テストのスコアの改善度（前後でのスコアの差） では有意差は認めなかったものの，プレテストの スコアで調整したプレテストとジャーナルクラブ 直後のポストテストのスコアの差は TBL 群にお いて有意に高かった。 また長期間スコアが維持さ れる傾向にあったことから，薬剤師教育において TBL 形式は講義形式に比べて有用である可能性 が示された。

TBL 群のジャーナルクラブ直後のポストテス トのスコアは講義群に比べて有意に高かった（ $P$ $<0.01$, 図 5A). 本研究において, TBL 群と講義 群の教育内容について完全に同等にすることは困 難ではあったが, 1 名の教育者が 2 群の教育内容 を可能な限り同一とし，教育手法のみ異なるよう に努めた，本研究では, 教育手法の差以外の交絡 因子を可能な限り排除するためプレテストのスコ アと薬剂師歴を基に TBL 群と講義群の 2 群にラ ンダム割り付けを実施するデザインとした。その うえでジャーナルクラブ時に, アンケート項目 「（3）予習時間」および「（4）今回のジャーナル クラブ参加前のモチベーション」を追加調査する ことで, 両群でジャーナルクラブ前の参加者背景 に著しい差がないことを確認することを計画し た.アンケートの結果, 「(3) 予習時間」は講義 群で有意に長かったため,「（3）予習時間」ある いは「（4）今回のジャーナルクラブ参加前のモ チベーション」がポストテストのスコア上昇に寄 与する可能性について多変量解析により解析した が, 有意な因子とならなかった（結果にデータ示 さず). 従って, TBL 群での直後のポストテスト のスコアが講義群での直後のスコアよりも高かっ た要因は，両群の参加者の資質やモチベーション というよりも, 教育手法の違いと考える. TBLに おける GRAT は学習者が予習で獲得した自分の知 識を用いて討論し, チームを正解に導かなければ ならない責任の場をつくり出すとされる. ${ }^{4)}$ 本研究 の TBL 群の参加者においても GRATの点数は IRAT の点数よりも高く, チーム学習の効果を認め た. GRATが学習者に適度なプレッシャーを与え つつ知識習得を促していることに加え, 症例を用 いた応用課題を提示することでグループ内での共 
同作業や議論を活発化したため, ポストスコアが 有意に高くなったと考えられる.

主要評価項目であるプレテストと直後ポストテ ストのスコア差において, TBL 形式と講義形式 とで有意な差は認められなかった。この原因とし て, 本研究で使用したテストの出題内容が基礎的 な内容であり, ポストテストで多くの参加者が満 点に近い点数を得点したことから，天井効果に よって TBL の講義に対する優越性が検出できな かった可能性がある。 また我々は，ジャーナルク ラブの実施によりもたらされる効果として, 直後 の学習効果とともに本質的な知識の定着も重要で あると考え，1 カ月後のポストテストに及ぼす影 響を検討した．本研究に扔ける 1 カ月後のスコア は TBL 群において維持される傾向にあったもの の両群のスコアに有意差は認められなかった。こ の要因としては, 本研究が単回の TBLによる教 育効果を比較したことに加え, 当日の参加者の減 少によるサンプルサイズ不足が考えられる。

本研究の TBL 形式では, 教育者は薬剤師 1 名で, 60 分間セミナーを進行することができた。薬剤 師を対象とした卒後教育においては，マンパワー やスペースの観点から，日常的な PBLの導入は 困難である場合が多い，従って，薬剤師を対象と した教育手法としては，本研究で用いた TBL 形 式がアクティブラーニングのなかでも有用な手法 の 1 つであると考えられる。一方で, 本研究では, 講義形式と TBL 形式のそれぞれのジャーナルク ラブを開催するために教育者が準備に必要とした 時間を比較検討していない. 今回は同一の担当者 が講義と TBL 両方の準備を行ったため, 直接的 なエフォートの比較は困難である。薬剤師を対象 とした卒後教育において, 教育者が事前準備に要 する時間は短いほうが望ましいと考えられるた め, 今後複数の担当者に対して準備時間などを記 録してもらい，エフォートの把握をすることが課 題であると考える，また，本研究では TBLに含 まれるピア評価（同僚評価）を省略した。ピア評 価は，TBLにおいて自分のチームのメンバーに 点数を割り振って評価するという過程であり, 受 け入れが良好であったという報告もあるが, ${ }^{177}$ 省 略した場合においても TBL の特徵を残した教育
効果を得ることができたと考える

学習者の満足度評価に関するアンケート調査で は, 講義群および TBL 群のジャーナルクラブに 対する満足度に有意差は認めなかった。これは, 講義形式のジャーナルクラブに対し一定の満足度 が得られていたためと考えられる.また,アンケー トに TBLに対する自由記載欄を設けていなかっ たため, 本研究期間において学習者へのインタ ビューや他者評価による行動変容の評価を行って はいない. TBL 群のジャーナルクラブ参加者に 対してジャーナルクラブ実施 5 カ月後に個別に 行った TBL 形式のジャーナルクラブについての 自由記載のアンケート調査では,「グループ形式 が良かった」や「ピア評価がなくてよかった」,「楽 しく論文抄読ができた」という回答が得られたこ とから (結果にデー夕示さず), 一定の評価を得 たと考える.

顧客満足度分析の結果では,「グループでのア ピール」や「グループのメンバーの多様性」など, グループ作業に関連する項目は重視しているが満 足度が低いことが示された。これは，本研究にお いて TBL 群のジャーナルクラブ当日の参加者が 10 名であったため, 通常推奨されているグルー プ人数よりもやや少ない人数での実施となったこ とが一因であると考えられる。 また, 学習者が重 視しているにもかかわらず満足度が低く, 優先的 に改善すべき項目には「RATのフィードバック」 も含まれ, 参加者は能動的学習に加え, 受動的知 識の伝達も望んでいることが明らかとなった。さ らに, 満足度の高い重要維持項目に「司会者の熱 意」や「論文内容の解説」があり, 学習者は教育 者からのアプローチや知識の伝達を重視し満足し ていることが示された。この点に関しては講義形 式のジャーナルクラブに扔いて $77.9 \pm 16.7 \%$ と 高い満足度であったことと矛盾のない結果と考え られる. 以上, 能動的な学習のみならず受動的な 学習を取り入れることが学習者の満足度を向上さ せるためには重要であり, また能動的学習法に関 してメンバー構成に充分な満足感を得られていな かったことから, 今後メンバー構成やグループの 人数について再考する必要があると考えられた。 本研究の限界として, 本研究は講義抢よび 
TBLを各 1 回しか行っていない.これまでの研 究から，TBLは継続することによって予習時間 も増え, 学習効果が高まるという報告もあるが, ${ }^{2}$ 本研究では単回の学習効果を比較したため, 薬剤 師の卒後教育として TBL を継続的に行うことの 有用性については，今後さらなる検討が必要と考 えられる。また，ジャーナルクラブの実施は業務 後に行ったため, 業務の都合上不参加となった者 が TBL 群で 4 名, 講義群で 2 名存在した。また, 1 カ月後のポストテストでもさらに不参加者が TBL 群で 3 名, 講義群で 1 名存在した。そのため, 事前に設定したサンプルサイズを確保できず，検 出力が不十分となったと考えられる。 また，一般 に TBL におけるチーム構成人員は 5〜7名が適切 とされている。しかし，本研究においては，1グ ループあたり 3〜4名となり通常推奨されている グループ人数よりもやや少ない人数での実施と なった。これにより TBL 群の学習効果を低下さ せた可能性は否定できない。 さらに，ジャーナル クラブの学習効果を正確に評価するためには，プ レテストの直後にジャーナルクラブを行うべきで あるが，プレテストのスコアを割り付け因子とし てランダム化し, ジャーナルクラブの日程調整を 行ったため, プレテストからジャーナルクラブの 実施までに 2 力月の期間を要した。また，参加者 の元々の資質である知識量や知識レベルをプレテ ストで完全に評価することは困難であるため, 参 加者の潜在的な能力がポストテストのスコアに及 ぼす影響を完全に除外することはできていないこ とが, 本研究の限界として挙げられる.

以上, 本研究で行った TBL 形式は講義などの 一方向性の受動的な手法に比べ, グループ内の共 同作業や議論により，直後の教育効果の向上とと もに長期的な効果も期待できる可能性が示され た. TBL は従来の講義形式から発展してきた学 習法であり, 米国の薬学教育においては, 専門教 育で早期から TBLを導入し，成果が得られたと 報告されている. ${ }^{18)}$ 本研究における顧客満足度分 析の結果からすれば（図 6)，「司会者の熱意」お よび「論文内容の解説」の質を維持しながら,「グ ループでのアピール」の時間を十分にとり，「グ ループのメンバーの多様性」を高めるために, 薬

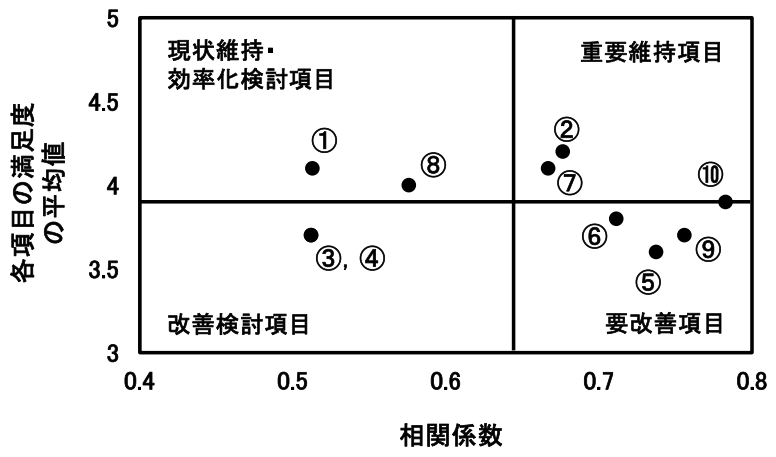

図 6 アンケート結果を用いた顧客満足度分析 (1)論文のテーマ, (2)司会者の熱意, (3) IRAT, (4) GRAT, (5)グルー プでのアピール, (6) RAT のフィードバック, (7)論文内容の解説, (8)応用課題，(9)グループのメンバーの多様性，(10)時間配分

剤師歴の長い薬剤師にも積極的に参加するよう促 すことで，より一層充実した TBL を実施できる と考えられる.

\section{謝 辞}

本研究の実施にあたり，協力していただいた当 院薬剂部の皆様に心より感謝申し上げます.

\section{利益相反}

開示すべき利益相反はない.

\section{引用文献}

1）亀井浩行, 半谷眞七子, 平野正美, 松葉和久, 薬学 教育への PBL (Problem-based Learning) の普及・ 導入状況に関するアンケート調查, 医療薬学, 2007, 33, 235-244.

2) Suno M, Yoshida T, Koyama T, Zamami Y, Miyoshi T, Mizushima T, Tanimoto M, Effectiveness of TeamBased Learning (TBL) as a new teaching approach for pharmaceutical care education, YAKUGAKU ZASSHI, 2013, 133, 1127-1134.

3) Takeda K, Takahashi K, Masukawa H, Shimamori Y, Influence on learning of a collaborative learning method comprising the jigsaw method and problembased learning (PBL), YAKUGAKU ZASSHI, 2017, 137, 659-664.

4）三木洋一郎, 瀬尾宏美, 新しい医学教育技法 $\lceil$ チーム基盤型学習 (TBL) 」, 日本医科大学医学 
会雑誌, 2011, 7, 20-23.

5) Sato A, Morone M, Azuma Y, Effects of implementation of problem-based learning tutorials on fifth-year pharmacy students and future issues, YAKUGAKU ZASSHI, 2011, 131, 1369-1382.

6) Michaelsen LK, Knight AB, Fink LD, “Team-based learning: a transformative use of small groups in college teaching”, Stylus Publishing, Sterling, VA, 2004, pp7-27.

7) Haidet P, Levine RE, Parmelee DX, Crow S, Kennedy F, Kelly PA, Perkowski L, Michaelsen L, Richards $\mathrm{BF}$, Guidelines for reporting team-based learning activities in the medical and health sciences education literature, Acad Med, 2012, 87, 292-299.

8) Thrall GC, Coverdale JH, Benjamin S, Wiggins A, Lane CJ, Pato MT, A randomized controlled trial of team-based learning versus lectures with break-out groups on knowledge retention, Acad Psychiatry, 2016, 40, 755-760.

9) Fatmi M, Hartling L, Hillier T, Campbell S, Oswald $\mathrm{AE}$, The effectiveness of team-based learning on learning outcomes in health professions education: BEME Guide No. 30, Med Teach, 2013, 35, e1608e1624.

10) Bleske BE, Remington TL, Wells TD, Klein KC, Guthrie SK, Tingen JM, Marshall VD, Dorsch MP, A randomized crossover comparison of team-based learning and lecture format on learning outcomes, Am J Pharm Educ, 2016, 80, article 120. doi: 10.5688/ajpe807120.

11) Takeuchi H, Omoto K, Okura K, Tajima T, Suzuki Y, Hosoki M, Koori M, Shigemoto S, Ueda M, Nishigawa K, Rodis OM, Matsuka Y, Effects of team-based learning on fixed prosthodontic educa- tion in a Japanese School of Dentistry, J Dent Educ, 2015, 79, 417-423.

12) Hemmati Maslakpak M, Parizad N, Zareie F, The impact of team-based learning on nervous system examination knowledge of nursing students, J Caring Sci, 2015, 4, 331-339.

13) Norose T, Ito M, Endo K, Fujimoto T, Moriya H, Murakami M, Introduction of team-based learning to the pharmacy experiential practice course for first-year pharmacy students, YAKUGAKU ZASSHI. 2014, 134, 179-183.

14）成瀬 均, 高橋敬子, 鈴木敬一郎, チーム基盤型 学習の導入経験, 医学教育, 2013, 44, 397-405.

15) Hatta K, Kishi Y, Wada K, Takeuchi T, Odawara T, Usui C, Nakamura H; DELIRIA-J Group, Preventive effects of ramelteon on delirium: a randomized placebo-controlled trial, JAMA Psychiatry, 2014, 71, 397-403.

16）相良英憲, 北村佳久, 古野勝志, 柴田和彦, 五味田 裕, Customer Satisfaction (CS) 分析を応用した実 務実習モデル・コアカリキュラム実施における 改善項目の抽出, 医療薬学, 2006, 32, 295-305.

17) Yasuhara T, Konishi M, Nishida T, Kushihata $T$, Sone T, Kurio W, Yamamoto Y, Nishikawa T, Yanada K, Nakamura M, Practical chemistry education provided by team-based learning (TBL) and peer evaluation, YAKUGAKU ZASSHI, 2014, 134, 185194.

18) Letassy NA, Fugate SE, Medina MS, Stroup JS, Britton ML, Using team-based learning in an endocrine module taught across two campuses, Am J Pharm Educ, 2008, 72, article 103. doi:10.5688/ aj7205103. 